
JETE : VOL 2 NO $12021 *$ E-ISSN : 2745-9888 * P-ISSN : 2745-9896
Journal of Education and Teaching
http://ejournal.uin-suska.ac.id/index.php/JETE

\title{
A COMPARATIVE STUDY ON THE EFFECT OF USING PQ4R AND ETR STRATEGIES ON STUDENTS' READING COMPREHENSION AT SMP PLUS TERPADU PEKANBARU
}

\author{
${ }^{1}$ Rizky Nugrahayu \\ ${ }^{1}$ UIN Sultan Syarif Kasim Riau, Indonesia \\ Email: ${ }^{1}$ rizkynugrahayu26@gmail.com
}

Received: 30 Oktober 2019; Accepted 28 Mei 2021; Published 31 Mei 2021

Ed 2021; 2 (1): 22-33

\begin{abstract}
ABSTRAK
Tujuan dari penelitian ini adalah untuk mengetahui perbandingan strategi Preview, Question, Read, Reflect, Recite and Review (PQ4R) dan Experience-Text-Relationship (ETR) pada Pemahaman Membaca Siswa. Desain penelitian adalah eksperimen semu dengan membandingkan dua strategi, dan dua kelompok eksperimen dengan desain pre-test dan post-test. Penelitian ini melibatkan 64 partisipan yang terdiri dari 32 siswa kelompok eksperimen 1 dan kelompok eksperimen 2 di SMP Plus Terpadu Pekanbaru. Ada 3 pertanyaan penelitian dengan 3 hipotesis yang diajukan dalam penelitian ini untuk mengidentifikasi perbedaan yang signifikan antara pengaruh penggunaan Strategi PQ4R dan ETR terhadap pemahaman membaca siswa. Pre-test dan post-test diberikan dalam penelitian ini untuk dua kelompok eksperimen. Uji-t sampel independen dan uji-t sampel berpasangan digunakan untuk menganalisis data. Hasil penelitian menunjukkan bahwa tidak ada perbedaan yang signifikan nilai rata-rata post-test antara kelompok eksperimen 1 yang diajar dengan menggunakan Strategi PQ4R dan ETR terhadap pemahaman bacaan siswa. Kontribusi strategi PQ4R untuk meningkatkan pemahaman membaca siswa sebesar 83\% sedangkan strategi ETR 85\%. Akhirnya, dapat disimpulkan bahwa Strategi PQ4R dan ETR dapat diterapkan dalam meningkatkan Pemahaman Membaca Siswa di SMP Plus Terpadu Pekanbaru.
\end{abstract}

Kata Kunci: Pemahaman Membaca, Strategi PQ4R, Strategi ETR.

\section{A COMPARATIVE STUDY ON THE EFFECT OF USING PQ4R AND ETR STRATEGIES ON STUDENTS' READING COMPREHENSION AT SMP PLUS TERPADU PEKANBARU}




\begin{abstract}
The aim of this study is to investigate the comparison of Preview, Question, Read, Reflect, Recite and Review (PQ4R) and Experience-Text-Relationship (ETR) strategies on Students' Reading Comprehension. The research design was quasi-experimental by comparing two strategies, and two experimental groups with pre-test and post-test design. This research involves 64 participants which consisted of 32 students from experimental group 1 and experimental group 2 at SMP Plus Terpadu Pekanbaru. There were 3 research questions with 3 hypothesis proposed in this research in order to identify the significant difference between the effect of using PQ4R and ETR Strategies on students' reading comprehension. Pre-test and post-test were administered in this study to two experimental groups. Independent sample t-test and paired sample t-test were used to analyzed the data. he research finding indicated that there was no significant difference of post-test mean score between an experimental group 1 which was taught by using PQ4R and ETR Strategies on students' reading comprehension. The contribution of PQ4R strategy to improve students' reading comprehension was $83 \%$ while ETR strategy was $85 \%$. Finally, it can be concluded that both PQ4R and ETR Strategies can be implemented in improving Students' Reading Comprehension at SMP Plus Terpadu Pekanbaru
\end{abstract}

Keyword: Reading Comprehension, PQ4R Strategy, ETR Strategy.

\title{
INTRODUCTION
}

Reading is an essential part of four language skills which must be mastered by the students. By having reading skill, the students can get a lot of information, knowledge, or widest insight. To acquire the information of reading text, the students should have good comprehension. A good reading comprehension will guide the students to find out the meaning of the context, explicitly or implicitly. Besides, a good comprehension is necessary to comprehend meaning what the author writes. In accordance with the statement above, Nunan (2005: 69) indicates that reading is a set skills that involves making sense and deriving meaning from the printed word. Also, Nuthall (1982: 85) states that the meaning gained from reading contains alphabetic and sounds transferred from writer to readers. In order to read, the reader must be able to decode (sound out) the printed words and also comprehend what he or she reads.

Furthermore, Duffy (2009: 14) states that comprehension is the essence of reading because the goal of the written language is communication of the message. If the reader do not understand the message, they are not reading. It means, comprehension is the center of reading. Readers should use the previous knowledge, strategy and skill to comprehend the text because Comprehension becomes the most important factor to indicate how well the readers read. So, reading comprehension is when the reader can apply it effectively.

In Indonesia, the teacher used different ways of teaching reading, like use a strategy to make students' are able to understand the content or meaning contained in the text. To talk about the strategy, every teachers have their own choice to teach in the classroom. Even the same teacher sometime use different strategy, it depends on the context of the lesson. It does not make sense if the teachers use only one strategy as long as they taught in 
a very long time. The students are difficult to be interested in that lesson if the teacher teaches the same way. How the teacher teaches in very important to be attentional because if the students are interested in the teacher, the students will be easier to be interested in the lesson.

Indonesia government is now also set to teach the lessons including English lessons in accordance with the curriculum that has been in effect, it is 2013 curriculum. In the 2013 curriculum, the subjects facing students must be integrated with the values of the nation's character. In Junior High School level, reading is one of the most important elements to be acquired in teaching and learning. In order to accomplish students' needs on reading, 2013 curriculum provides reading as one of the skills in English mastery that must be taught and learned in the school.

Junior High School Plus Terpadu Pekanbaru is one of schools that also implies 2013 curriculum as is guidance in teaching and learning process. Based on preliminary study at Junior High School Plus Terpadu Pekanbaru, the one of English teacher explained about teaching and learning process in the class about the students' English achievement and some factors that teacher looked at the students' condition in teaching and learning process. The teacher said that English is taught twice a week with time duration about 80 minutes for each meeting and the minimum students' passing grade of English is 75 . In fact, the some of the students are not passed in it.

The teacher informed that she still have got problems in teaching reading. More students of Junior High School Plus Terpadu Pekanbaru are not able to identify the main idea of the text, to find the specific information in the passage and to find the meaning of vocabulary. Then, some of them are difficult to answer the questions related to the content of the text given.

Moreover, the teacher said there are some phenomena happened in the class about some factors made the students get low scores. Some students are still passive in the class. It could be seen when the teacher gave the students time to discuss about the topic, the students always keep silent when the teacher gave them chances to ask about the topic. The teacher also explained that the students had difficulties in comprehending reading text. First, the students were difficult to comprehend the text easily and felt confused to find the meaning of difficult word. Second, the students were difficult to find main idea and make the conclusion. It caused the students were confused what should they do and still had poor vocabulary. Third, the students were hard to make connection between their experiences and presented in a given text. It caused the students did not know what the text is about. Because of those problems, the students got different achievement in English, especially in reading comprehension.

Based on the problems that researcher found, the students' reading comprehension in narrative text need an appropriate strategy to overcome their problems, that can make them passed in the criterial of students' minimum passing grade. There are strategies that can help students' reading comprehension in reading, they are PQ4R (Preview, Question, Read, Reflect, Recite and Review) and ETR (Experience-Text-Relationship) strategies.

In line with this idea, Slavin (1994) states that one of the strategies which can help students to understand reading text is PQ4R. PQ4R is a strategy that guides the students to understand reading text based on the steps. The steps covers preview, question, read, recite, reflect and review. PQ4R strategy can help the students focus in organizing information and 
making it meaningful. Therefore, in learning reading comprehension, students can be more active to express their idea or opinion. In this case, PQ4R strategy can give good solution for teacher and students to get the education successful. As an expectation, by applying this strategy can help students in comprehending and understanding the text and students are able to focus more on reading comprehension easily and well.

Besides PQ4R, other strategy that can be used by some English teachers is ETR (Experience-Text-Relationship) strategy. Wood $(2009 ; 135)$ state that Experience-TextRelationship (ETR) is a strategy that draws on background knowledge and prior knowledge and experience. In addition, Carr $(2004 ; 90)$ said that this strategy promotes thoughtful reader to narrative text. This strategy helps learners to active and build knowledge to facilitate both reading motivation and comprehension and be useful for narrative text. In conclusion, both of strategies are suitable to teach in reading comprehension in topic of narrative text.

\section{METHOD}

The design of the research was a quasi-experimental research. According to Gay (2000: 364), the quasi-experimental design involves selecting two groups or more differing on some independent variables and comparing them to some dependent variables. The groups may differ in a number of ways. One group may possess a characteristic that the other does not, one group may possess more of a characteristic than the other, or the two groups may have had different kind of experiences.

Therefore, there were three variables used in this research; PQ4R (Preview, Question, Read, Reflect, Recite and Review) Strategy (X1) and ETR (Experience-Text-Relationship) Strategy (X2) were independent variables, while the students' reading comprehension (Y) was dependent variable. Gay (2000: 367) states that experimental research is the only type of research that can hypothesis to establish cause-and-effect relationships.

Gay (2000: 354) states that definition and selection of comparison group are very important parts of the quasi experimental design procedure. The independent variable which differentiates the group must be clearly and operationally defined since each group represents a different population. The way in which the group is defined will affect the generalize ability of the results.

The participants of the study consisted of 64 students from 347 of grade 8 of Junior High School Plus Terpadu Pekanbaru. The technique used to select the sample of this study was cluster sampling technique, because the sample was selected based on group, not individually. According to Gay (2000:12), cluster sampling randomly selects group, not individual. All the members of selected groups have similar characteristics. The number of sample was 64 students each of which VIII A was treated as the experimental group 1, and VIII B was treated as the experimental group 2.

The data were obtained by using a pre-test and a post-test. The questions for the pretest and posttest were the same because the pretest questions was used to determine the 
students' abilities before using the strategy and the posttest questions was used to determine of the students' abilities after using the strategy.

Slavin (1994) in Allen (2008; 25) explained that there are step of PQ4R strategy, as follows: a) The teacher gives a text to read for the students; b) The teacher asks students to previewing the narrative text by scanning the title or reading the sentence at the beginning or end of the paragraph; c) The teacher informs the students to pay attention to the meaning of the passage, and give students' assignments to make the question from the text referring to $5 \mathrm{~W}+1 \mathrm{H}$ (what, who, when, where, why and how); d) The teacher instructs the students to reread the text carefully and answer the questions that had been prepared before; e) The teacher asks students to reflect information or to think back on the material learnt to check how much the student has learned and what they have not understood; f) The Teacher divides students into groups. Then, to practice remembering the information, the teacher guides each group has a discussion by exchanging opinions about the answers found in the text; g) The teacher asks students to reread the summary at the end of the text, and asks them to look back over the material, paying special attention to the key ideas they have found. Focusing on asking their self-questions, re-read the material only when they are not sure of the answers.

There are some procedures or steps in implementation of experience-text-relationship strategy, as follows: a) The teacher shows a picture to the students; b) The teacher asks some questions related to the pictures presented to activate students background knowledge; c) The teacher lets the students read the shorts parts of the texts, usually a page or two; d) The teacher explains about the generic structure and language features of a narrative text; e) The teacher gives another picture to the students; f) In groups, the students make their prediction according to their experiences toward the characters of the picture; $g$ ) The teacher distributes the text and has the students to read the text while guiding them with questions to avoid misunderstanding; h) The students guided by the teacher discuss the purpose, generic structure and language features of the tex; i) The teacher has the student to summarize the story and to review the key events and issues; j) The students draw relationships between information from the text and their previous prediction (experience or prior knowledge) and make a conclusion, and then present the result in front of the class.

The PQ4R and ETR Strategies lead the students to be creative thinking, imaginative, and joyful learning to achieve the objectives of the lesson. Besides, teaching and learning process automatically becomes a student-centered instruction with modern pedagogy through the integration of the strength of attitude, skill and knowledge. 


\section{RESULT AND DISCUSSION}

\section{RESULT}

The test scores from the students test reading comprehension results were analyzed by using quantitative data analysis for the findings. Both descriptive and inferential statistical analysis are included. Frequently counts, percentages, mean scores and standard deviation of the variables were presented in the descriptive analysis. The hypotheses developed for this research were tested using independent sample t-test and paired sample t-test.

\begin{tabular}{|l|l|l|l|l|}
\hline & $\mathrm{N}$ & Sum & Mean & $\begin{array}{c}\text { Std. } \\
\text { Deviatio } \\
\mathrm{n}\end{array}$ \\
\hline $\begin{array}{l}\text { Pre-test } \\
\text { EG 1 }\end{array}$ & 32 & 1915 & 59.84 & 7.77 \\
\hline $\begin{array}{l}\text { Post-test } \\
\text { EG 1 }\end{array}$ & 32 & 2570 & 80.31 & 5.37 \\
\hline $\begin{array}{l}\text { Pre-test } \\
\text { EG 2 }\end{array}$ & 32 & 1925 & 60.15 & 7.98 \\
\hline $\begin{array}{l}\text { Post-test } \\
\text { EG 2 }\end{array}$ & 32 & 2640 & 82.50 & 5.67 \\
\hline $\begin{array}{l}\text { Valid N } \\
\text { (list } \\
\text { wise) }\end{array}$ & 32 & & & \\
\hline
\end{tabular}

Table 1.

Results of students' reading comprehension pre-test and post-test scores

Based on the table 1, it can be determined that the number of participants at Junior High School Plus Terpadu Pekanbaru in the experimental group 1, and 2 were 32 students. The table displays that the experimental group 2 was the highest pre-test mean score (60.15) with the standard deviation is 7.98 and post-test mean score (82.50) with the standard deviation is 5.67 .

3 (Three) hypotheses were analyzed by using inferential statistics as follows:

\section{Hypothesis 1}

$\mathrm{H}_{0} 1$ : There is a significant difference on students' reading comprehension pre-test and posttest mean score by using PQ4R strategy of the experimental group 1 at SMP Plus Terpadu Pekanbaru.

Table 2. The Analysis of Paired Sample T-test between Pre-Test and Post-Test on Students' Reading Comprehension for an Experimental Group 1 


\begin{tabular}{|c|c|c|c|c|c|c|c|}
\hline & & Mean & $\mathrm{N}$ & $\begin{array}{c}\text { Std. } \\
\text { Deviation }\end{array}$ & $\mathrm{t}$ & $\mathrm{df}$ & $\begin{array}{c}\text { Sig. } \\
(2- \\
\text { tailed) }\end{array}$ \\
\hline \multirow{2}{*}{$\begin{array}{l}\text { Pair } \\
1\end{array}$} & PreTest & 59.84 & 32 & 7.77 & & \multirow[t]{2}{*}{31} & \multirow[t]{2}{*}{.000} \\
\hline & PostTest & 80.31 & 32 & 5.37 & 13.11 & & \\
\hline
\end{tabular}

Based on the table above, it can be seen that the total number of students in experimental group 1 consisted of 32 students. The mean of pretest was 59.84 and the mean of posttest was 80.31. The standard deviation of pretest was 7.77, and the posttest was 5.37. t-test result was 13.11, it is compared by getting the degree freedom (df) 31 significance was 0.00 .

By comparing $\mathrm{t}_{\mathrm{o}}$ ( $\mathrm{t}$-obtained) $\mathrm{t}_{\mathrm{o}}$ is $\mathrm{T}$-table from $\mathrm{df}=30$, the level of significance of $5 \%$ was 2.04 and the level of significance $1 \%$ was 2.75 . It can be seen that $2.04<13.111>$ 2.75. It means that the null hypothesis $\left(\mathrm{H}_{\mathrm{o}}\right)$ is rejected and the alternative hypothesis $\left(\mathrm{H}_{\mathrm{a}}\right)$ is accepted.

\begin{tabular}{|l|l|l|l|l|l|l|l|}
\hline & & & & & & & $\begin{array}{l}\text { Sig. } \\
(2- \\
\text { tailed })\end{array}$ \\
\hline $\begin{array}{l}\text { Pair } \\
1\end{array}$ & PreTest & 60.15 & 32 & 7.98 & 12. & & \\
\cline { 2 - 5 } & 82.50 & 32 & 5.67 & 74 & 31 & .000 \\
\hline
\end{tabular}

By comparing number of significance, if probability $>0.05$, null hypothesis $\left(\mathrm{H}_{\mathrm{o}}\right)$ is accepted. If probability $<0.05$, alternative hypothesis $\left(\mathrm{H}_{\mathrm{a}}\right)$ is accepted. Because significance is $0.000<0.05$, thus $\mathrm{H}_{\mathrm{a}}$ is accepted while $\mathrm{H}_{\mathrm{o}}$ is rejected.

Then, the percentage of significant effect is found out between pre-test and post-test of an experimental group 1 by looking for the effect size or eta-squared as follows:

$\eta^{2}=\frac{t^{2}}{t^{2}+n-1}$

$\eta^{2}=\frac{13.111^{2}}{\left(13.111^{2}\right)+32-1}$

$\eta^{2}=\frac{171.898}{171.898+31}$

$\eta^{2}=\frac{171.898}{202.898}=0.83$

Eta-Squared $=\eta^{2} \times 100 \%$

Eta-Squared $=0.83 \times 100 \%=83 \%$

The result of data analysis is based on inferential statistics which has been identified that after conducting the treatment for 4 meetings or 8 class-hours by using PQ4R strategy 
can improve $83 \%$ on the reading comprehension. Therefore, the $\mathrm{H}_{\mathrm{o}} 1$ hypothesis is rejected and $\mathrm{H}_{\mathrm{a}} 1$ is accepted that there is significant difference on students' reading comprehension pre-test and post-test mean score by using PQ4R Strategy of the experimental group 1 at Junior High School Plus Terpadu Pekanbaru.

\section{Hypothesis 2}

$\mathrm{H}_{\mathrm{o} 2}$ : There is a significant difference on students' reading comprehension pre-test and posttest mean score by using ETR strategy of the experimental group 2 at SMP Plus Terpadu Pekanbaru.

\section{Table 3. The Analysis of Paired Sample T-test between Pre-Test and Post-Test on Students' Reading Comprehension for an Experimental Group 2}

Based on the table above, it can be seen that the total number of students in experimental group 2 consisted of 32 students. The mean of pretest was 60.15 and the mean of posttest was 82.50. The standard deviation of pretest was 7.98 and the posttest was 5.67. t-test result was 12.74, it is compared by getting the degree freedom (df) 31 significance was 0.000 .

By comparing $\mathrm{t}_{\mathrm{o}}$ ( $\mathrm{t}$-obtained) $\mathrm{t}_{\mathrm{o}}$ is $\mathrm{T}$-table from $\mathrm{df}=30$, the level of significance of $5 \%$ was 2.04 and the level of significance $1 \%$ was 2.75 . It can be seen that $2.04<12.744>$ 2.75. It means that the null hypothesis $\left(\mathrm{H}_{\mathrm{o}}\right)$ is rejected and the alternative hypothesis $\left(\mathrm{H}_{\mathrm{a}}\right)$ is accepted.

By comparing number of significance, if probability $>0.05$, null hypothesis $\left(\mathrm{H}_{\mathrm{o}}\right)$ is accepted. If probability $<0.05$, alternative hypothesis $\left(\mathrm{H}_{\mathrm{a}}\right)$ is accepted. Because significance is $0.000<0.05$, thus $\mathrm{H}_{\mathrm{a}}$ is accepted while $\mathrm{H}_{\mathrm{o}}$ is rejected.

Then, the percentage of significant effect is found out between pre-test and post-test of an experimental group 2 by looking for the effect size or eta-squared as follows:

$\eta^{2}=\frac{t^{2}}{t^{2}+n-1}$

$\eta^{2}=\frac{12.744^{2}}{\left(12.744^{2}\right)+32-1}$

$\eta^{2}=\frac{162.409}{162.409+31}$

$\eta^{2}=\frac{162.409}{193.409}=0.85$

Eta-Squared $=\eta^{2} \times 100 \%$

Eta-Squared $=0.85 \times 100 \%=85 \%$

The result of data analysis is based on inferential statistics which has been identified that after conducting the treatment for 4 meetings or 8 class-hours by using ETR strategy can improve $\mathbf{8 5 \%}$ on the reading comprehension. Therefore, the $\mathrm{H}_{\mathrm{o}} 2$ hypothesis is rejected and $\mathrm{H}_{\mathrm{a}} 2$ is accepted that there is significant difference on students' reading comprehension 
pre-test and post-test mean score by using ETR Strategy of the experimental group 2 at Junior High School Plus Terpadu Pekanbaru.

\section{Hypothesis 3}

$\mathrm{H}_{\mathrm{o}} 3$ : There is no significant difference on students' reading comprehension post-test mean score between the experimental group 1 (PQ4R strategy) and the experimental group 2 (ETR strategy) at SMP Plus Terpadu Pekanbaru.

Table 4. The Analysis of Independent Sample T-test of Post-Test Reading Comprehension Scores between an Experimental Group 1 and an Experimental Group 2 at Junior High School Plus Terpadu Pekanbaru

\begin{tabular}{|l|l|l|l|l|l|l|l|}
\hline & Groups & $\mathrm{N}$ & Mean & $\begin{array}{c}\text { Std. } \\
\text { Devi } \\
\text { ation }\end{array}$ & $\mathrm{t}$ & df & $\begin{array}{c}\text { Sig. } \\
(2- \\
\text { tailed) }\end{array}$ \\
\hline $\begin{array}{l}\text { Post } \\
\text { Test }\end{array}$ & EG 1 & & & & - & & \\
& EG 2 & & 80.31 & 5.37 & 1.5 & 62 & .119 \\
& & 32 & 82.50 & 5.67 & 1.5 & 61. & .119 \\
\hline
\end{tabular}

Based on the table above, it can be seen that $\mathrm{t}_{\mathrm{o}}$ is -1.58 . The T-table was compared by getting the degree of freedom (df) 62. T-table in the degree of freedom of $5 \%$ and $1 \%$ significance was obtained 2.00 and 2.65. So, the researcher found that $2.00>-1.58<2.65$. It can be said that $\mathrm{H}_{\mathrm{o}}$ is accepted and $\mathrm{H}_{\mathrm{a}}$ is rejected. Whereas by comparing number of significance, if probability $>0.05$, null hypothesis $\left(\mathrm{H}_{\mathrm{o}}\right)$ is accepted. If probability $<0.05$, alternative hypothesis $\left(\mathrm{H}_{\mathrm{a}}\right)$ is accepted. Because the significance is $0.119>0.05$, thus $\mathrm{H}_{\mathrm{o}}$ is accepted while $\mathrm{H}_{\mathrm{a}}$ is rejected. The result showed that the mean score did not differ much between both groups. It could be determined that the subjects in both groups are equivalent after giving the treatment at Junior High School Plus Terpadu Pekanbaru.

Based on the analysis of table 4 , of the third hypothesis, $\mathrm{H}_{\mathrm{a}} 3$ is rejected and $\mathrm{H}_{\mathrm{o}} 3$ is accepted. So, it can be concluded that "there is no significant difference on students' reading comprehension post-test mean score between an experimental group 1 and an experimental group 2 at Junior High School Plus Terpadu Pekanbaru”.

\section{DISCUSSION}

Based on the data analysis of inferential statistics of an experimental group 1 using PQ4R strategy, it shows that there is significant improvement on students' reading comprehension pre-test and post-test mean score of an experimental group 1 using PQ4R strategy at SMP Terpadu Pekanbaru. Then, the percentage of significant effect between pre- 
test and post-test of an experimental group group 1 by looking for the effect size or etasquared as follows: Eta-Squared $=0.83 \times 100 \%=83 \%$.

The implementation of PQ4R strategy leads the students to be independent learners when they should prepare their own questions or summary from the texts given. By giving the students a chance to present their summary of the texts discussed, they were very happy to perform their best, therefore, they were challenged to do something creative.

Slavin (1994) in Sriadi (2012) says that PQ4R strategy is a strategy that helps students to focus organizing information in their minds and making it meaningful. Wahono (2014) state that The PQ4R Strategy helps to make individual to know what to learn. It focuses student' attention, increasing interest, relating new ideas to previously known concepts and building comprehension. The students are encouraged to actively interact with the material while reading by the following organizing techniques.

In addition, Sanacore (1983) explained that PQ4R strategy stimulates student' prior knowledge by using six steps; preview (activate prior knowledge), question, read, reflect, recite, and review. These latter steps confirm the knowledge activated in the preview and establish bridge of new knowledge.

Based on the data analysis of inferential statistics of an experimental group 2 using ETR strategy, it shows that there is significant improvement on students' reading comprehension pre-test and post-test mean score of an experimental group 2 using ETR strategy at SMP Terpadu Pekanbaru. Then, the percentage of significant effect between pretest and post-test of an experimental group 1 by looking for the effect size or eta-squared as follows: Eta-Squared $=0.85 \times 100 \%=85 \%$.

The students were so joyful during completing their ETR chart. They were busy to fill in the chart about what they have known and what they founded about the topic. Besides, they were also active in discussion with their friends. Through those activities, the students became motivated. They looked interested to continue reading because they wanted to know whether the content of the text was similar with the background knowledge they had.

Carrell, et al. in Pennington and Young (1989: 654). They state an important requirement of the ETR strategy is that the teacher be adept in leading the students to discover the correct answers for themselves, rather than telling them the answers directly. The goal of the strategy is to enable the students, who have had the processes modeled for them by the teacher, to use these same cognitive processes on their own.

The effectiveness of background knowledge activation in motivating the students is supported by the theory given by Carrell, et al. in Pennington and Young (1989: 654). They state in the experience step of ETR, the teacher leads the students in discussion of their own knowledge or experiences that are related in some way to the passage to be read. This is important not only because the students can activate any relevant prior background they 
may have and begin to relate it to the text to be read, but also because the experience step provides a motivation for reading the text.

Supporting the theory proposed by Pennington and Young above, Saunders et al. (1999: 10) state that drawing upon, sharing, and discussing students' relevant personal experiences as required in ETR strategy sustain motivation and help students make concrete and conceptual connections to the text, its content, and the themes under study.

Based on an Independent T-test analysis for post-test reading comprehension score of an experimental group 1 and an experimental group 2 on table 4, it shows that there is no significant difference at post-test reading comprehension between an experimental group 1 and an experimental group 2. T-test result is 0.119 , its df is 62 , standard deviation of an experimental group 1 is 5.37 and an experimental group 2 is 5.67. So, in the conclusion $\mathrm{p}=$ 0.119 , the 2 tailed value is bigger than 0.05 ( $\mathrm{p}>00.5$ ). The result shows that the mean scores did not differ much between both groups. It can be determined that the subjects in both groups are equivalent after giving the treatment at SMP Plus Terpadu Pekanbaru.

Based on the analysis of the third hypothesis $\mathrm{H}_{\mathrm{a}} 3$ is rejected and $\mathrm{H}_{\mathrm{o}} 3$ is accepted. So, it can be concluded that "There is no significant difference on students' reading comprehension post-test mean score between the experimental group 1 (PQ4R strategy) and the experimental group 2 (ETR strategy) at SMP Plus Terpadu Pekanbaru."

Both the experimental group 1 and experimental group 2 were taught by the same English teacher. Based on direct observation, the teacher succeeded to carry out both of the treatments as directed. It seemed, the students were joyful during the teaching and learning process whether in the experimental group 1 or in the experimental group 2 since they were directly involved in the process. Besides, the teacher was able to do good communication with the students.

\section{CONCLUSION}

The findings indicate that there is no significant difference between PQ4R and ETR strategies on students' reading comprehension. For both of them show the significant effect on the students' reading comprehension. However, the ETR strategy contributes a little bit more effect $(85 \%)$ compared to PQ4R strategy $(83 \%)$. As a reading strategy, PQ4R helps teacher engage students from the beginning on reading lesson so that they could access important background information in reading a text. On the other hand, the ETR strategy which builds building students' background knowledge prior to reading, helps students contextualizing story themes, content and vocabulary. The teachers should be alert and creative to prepare the materials or other facilities before teaching.

\section{REFERENCES}

Carrell, P. L. 1989. Metacognitive Strategy Training for ESL Reading.TESOL Quarterly, vol. 23 no. 4. 
Duffy, G Gerald. 2009. Explaining a Resources for Teaching Concepts, Skills, and Strategies. New York: The Guildford Press.

Gay, L.R and Peter Airasian. 2000. Educational Research Competences for Analysis and Application, 6thEdition. New Jersey: Prentice-Hall Inc.

Nunan, David. 2005. Practical English Language Teaching: Young Learners. New York: McGraw-Hill ESL/ELT

Nuttal, Christine. 1982. Teaching Reading Skill in a Foreign Language. London: The Nemman Educational Ltd

Wahono, Suparwoto Sapto. 2013. Using PQ4R to Increase the Students' Reading Comprehension at Al-Bidayah Islamic Boarding School Jember. Fenomena, Vol. 13, No. 2

Slavin, R.E. 1997. Educational psychology: theory and practice, Eight Edition. Massachusetts: Allyn and Bacon Publisher

Wood, Karen and Blanton, William E. 2009. Literacy Instruction for Adolescents. New York: A division of Guilford Publications, Inc 